\title{
SELF-EFFICACY FOR PHYSICAL ACTIVITY OF PEOPLE OVER 65
}

\author{
Silvia López Alonso \\ Grado en Psicología \\ Investigadora predoctoral de la Universidad de Valencia. \\ Dpto. de Psicogerontología: perspectiva del Ciclo Vital \\ masiloa@alumni.uv.es
}

Recepción Artículo: 2 noviembre 2020

Admisión Evaluación: 12 noviembre 2020

Informe Evaluador 1: 17 noviembre 2020

Informe Evaluador 2: 19 noviembre 2020

Aprobación Publicación: 27 noviembre 2020

\begin{abstract}
Professionals and researchers studying the care received by people over 65 stand by the benefits of physical activity to improve the quality of live. However, their analyses and field work show very low involvement rates of this group in physical activity programmes, a high reluctance to participate and, when done, this behaviour is hardly maintained over time. It is well known that self-efficacy is relevant to carry out an action, but there is no evidence suggesting that the same is true for physical activity. This study aims to find out if self-efficacy improves the attitude of the elderly towards physical activity; to define self-efficacy as a construct; to design and validate a self-efficacy scale regarding physical activity for people over 65; to analyse the response of a representative sample of over 65s from Valencia to this construct; and to find out if gender and age affect self-efficacy in relation to physical activity.

Keywords: elderly adults; autonomy; quality of life; scale

\section{RESUMEN}

Autoeficacia para la actividad física de las personas mayores de 65. Los profesionales e investigadores que estudian la atención que reciben los mayores de 65 años defienden los beneficios de la actividad física para mejorar la calidad de vida. Sin embargo, sus análisis y trabajos de campo muestran unas tasas muy bajas de participación de este colectivo en programas de actividad física, una alta reticencia a participar y, cuando lo hacen, este comportamiento apenas se mantiene en el tiempo. Es bien sabido que la autoeficacia es relevante para llevar a cabo una acción, pero no hay evidencias que sugieran que lo mismo ocurre con la actividad física. Este estudio pretende averiguar si la autoeficacia mejora la actitud de las personas mayores hacia la actividad física; definir la autoeficacia como constructo; diseñar y validar una escala de autoeficacia respecto a la actividad física para mayores de 65 años; analizar la respuesta de una muestra representativa de mayores de 65 años de Valencia a este constructo; y averiguar si el género y la edad afectan a la autoeficacia en relación con la actividad física.
\end{abstract}

Palabras claves: adultos mayores; autonomía; calidad de vida; escala 


\section{SELF-EFFICACY FOR PHYSICAL ACTIVITY OF PEOPLE OVER 65}

\section{Acknowledgements}

We want to thank D. Jesús R. López Gálvez who has allowed us to access the OMAM Centers, Jose Mํㅗ. Ravelo for his statistical advice, Nieves and Mํ José Rovira, Ernesto Vela and María Cerezo helped us collect part of the data. Also to Juan C. Meléndez Moral of the UV for his editorial advice.

\section{INTRODUCTION}

The idea of enjoying a healthy aging has led professionals to plan and predict what could be the best approach to face this life stage in order to optimise the quality of live (QoL) of elderly adults. It seems necessary to find some efficient action guidelines that could help reduce the impairments associated with age, in addition to prevent neurodegenerative illnesses, and to turn these guidelines into habits to maintain the necessary autonomy to carry out daily live activities (Casado \& Bárcena, 2017). The biopsychosocial model broadly recognises that people's health is not just good or bad and does not depend only on the illnesses suffered. Factors such as habits, lifestyle or environmental conditions (Bandura, 2004, p. 42; Engel, 2012; Hawkesworth et al., 2018; Kaiser, 2017) are determinant.

Firstly, because people adjust their conduct through some internal criteria and self-assessing reactions, such as the human nature and causality models (Bandura, 1987, p. 415; García et al., 2018). Secondly, because the ability to achieve and foresee motivates individuals to be efficient, to be willing to self-develop and self-control, and to influence the results (Bandura, 1987, p. 17; Meléndez, Satorres \& Delhom, 2020). In this sense, when symbolic regulatory processes combine with self-generated consequences, the conduct may be internalised or remain partially independent from the situational consequences and results (Bandura, 1983, p. 591). For this reason, insecure individuals tend to quickly interrupt the generating process as soon as the initial efforts developed prove to be ineffective.

\section{Self-efficacy according to Bandura}

Bandura states that there is a clear difference between having an ability and being able to use it under different circumstances. For this reason, different people with similar resources, or the same persons on different occasions, may display a poor, adequate or outstanding performance (Bandura, 1987, p. 416).

On one hand, a) it is possible to differentiate several intrinsic control reinforcement types; b) conduct might be maintained because of its inherent sensorial feedback due to the anticipation of the results or self-assessing consequences (Bandura, 1983, p. 591); c) the aim pursued by the efficacy will directly impact the biology and QoL of the individual himself (Bandura, 2004, p. 19); and d) the personal efficacy beliefs with regards to the environment are one of the core connectors of the individual functioning. On the other hand, judgements of the personal efficacy are more rooted in the emotional states, the intensity of the motivation and the individual's actions than in objective information. This means that the starting of personal efficacy beliefs, structure, function, operative processes and effects produced, implement and promote human nature (Bandura, 1983). The self-efficacy theory considers all these sub-processes at an individual and collective level. Perceived self-efficacy refers to an individuals' conviction on his abilities to sort and run the courses of action required, as well as to manage future scenarios. These so called efficacy beliefs integrate the individual's way to feel, think, self-motivate and act, and considerably promote stimulation and human achievements (Bandura, 2004, p. 21).

Among the different aspects involved in self-knowledge, possibly none of them is as influential in the daily life as the opinion an individual has about his own personal efficacy (Meléndez, Tomás \& Navarro, 2011; RuízMontero, Ramiro, Ramiro-Sánchez \& García, 2020). Self-efficacy is involved in the personal determination of the action (Bandura, 1987, p. 415). Judgement on the efficacy also determine the amount of effort that an individual is willing to put when facing obstacles and adverse experiences, as well as the amount of time he will be able to sustain such effort. The higher the perception of efficacy, the stronger and more persistent will be the efforts to overcome the challenge presented. While those individuals who feel insecure about their capabilities will reduce their efforts or just give up when facing difficulties (Bandura, 1987, p. 419). 


\section{Physical activity as part of a satisfactory aging}

Aging is a complex process that involves all the dimensions of the subject: biological, physical, motor and psychological (Garber et al., 2011; Kaiser, 2015); however, as already mentioned, in a large number of cases, it also means a limitation of independence when carrying out daily activities and this reduces the QoL and conditions the lives of those close to the individual (Casado et al., 2017; Cohen, 1979; Kingston et al., 2017). The World Health Organization (WHO, 2010, p. 25) states that physical inactivity is the fourth most important risk factor for mortality globally and that the practice of constant and planned exercise has proven to have a favourable impact on the body, reducing the risk of coronary heart disease and cerebrovascular accidents, type-2 diabetes, high blood pressure, colon cancer, breast cancer and depression.

A moderate daily physical activity allows the elderly person to generate health conducts such as exercise, follow a healthy food diet, supress toxic habits like sedentarism, recurrent ideas, bad mood, alcoholism or smoking (Ortíz-Alonso et al., 2020; Serra-Rexach et al., 2011) Ioneliness and depression (Brown, Kaiser \& Gellis, 2007; Kang, Park \& Wallace, 2018), and to carry out basic daily live activities, such as personal hygiene. When practiced outside home, this activity allows the elderly person to be outdoors, to walk and relate socially, improving the autonomy and self-esteem (IMSERSO, 2010; Pinazo, 2018). According to Lázaro, Doistua \& Lazcano (2019), the recommended physical activity for over 65 s includes recreation and leisure activities, walks, bicycle rides, domestic chores, games, sports or exercise programmes within the framework of daily, family and/or community activities. Wen, Li \& Su (2014) found that 15 min per day, or 90 minutes per week, of moderately strenuous exercise results in benefits in terms of life expectancy, which could increase by up to 3 years. Similarly, according to Myers et al. (2002), physical exercise practiced with the adequate frequency, intensity and duration is associated with a reduction of the global mortality and an increase of the life expectancy by 2-3 years. It is directly related with a higher bone density and fewer fractures, and the mineral gains are sustained during the aging process, even if he frequency of the activity is later reduced, protecting the elderly adult from sarcopenia (Faienza et al., 2020).

\section{Self-efficacy and physical activity for people over 65}

Seeing that the aging process conditions the QoL in the last stages of the lifecycle, professionals and researchers value good health, intelligence and the elderly person will to maintain his independence (Blazer, 2009, p. 6; Garber et al., 2011; Meléndez, Navarro, Oliver \& Tomás, 2009). In this respect, regular physical activity is relevant due to all the physiological, psychological, and social benefits it implies. But professionals and researchers confirm that, beyond 65 years of age, subjects are reluctant to participate in any physical activity. There is an important trend among the authors studied to consider that this group is aware of the health benefits derived from the physical activity, however, they do not get involved enough, only a small proportion reach the recommended levels. Jones (2006) states that in Canada, only $12 \%$ of people over 65 years of age participates in a physical activity with regularity. also indicate that people with a higher degree of self-efficacy. Fernández, Medina, Herrera, Rueda \& Fernández (2011) also indicate that people with a higher degree of self-efficacy show a higher adherence to physical activity programmes than people with lower levels of self-efficacy. They add that self-efficacy anticipates the conduct to practice a physical activity in the medium- and long-term because there is a significant relationship between the variable and the benefits of physical activity

Emile, Chalabaev, Stephan, Corrion \& d'Arripe-Longueville (2014) and Ruíz-Montero, Ramiro, Ramiro Sánchez \& García (2020) indicate that the physical self-esteem, better physical condition and health gained with physical activity are related to a positive perception of the own aging process and the willingness to continue practicing. The study conducted by Chaudhury, Campo, Michael \& Mahmood (2016) reveals that, although home and the social aspects of the neighbourhood affect in a positive way the willingness to get involved in a physical activity, the most influential factors in the long-term adherence to a physical activity programme for over 65 are that the programmes are recreational and that their friends participate too. Capalb, O'Halloran \& Liamputtong (2014) published that the involvement rates in physical activity programmes are low, and the real motivators for elderly people to partake depend on the programmes allowing them to socially interact and to make honest and loyal friendships. 


\section{SELF-EFFICACY FOR PHYSICAL ACTIVITY OF PEOPLE OVER 65}

A study by Franco et al. (2015) report that, in order to get a regular physical activity, having to use transport and paying for it were more determinant factors that the health benefits obtained. Consequently, the authors suggest that a motivational strategy to increase participation in these programmes should focus on improving accessibility. Cerin et al. (2018) explain that areas with a high population density, good public transport access and green areas significantly contribute to physical activity among elderly people globally. A study by Li-Tang, et al. (2016) points to a preference of elderly people for outdoors activities over physical activities indoors and within closed spaces and, in this respect, walking or doing the daily shopping are prevalent for them.

A study by Picorelli, Máximo, Sirineu, Felício \& Sherrington (2014) on adherence and withdrawal rates from physical activity programmes reports that these variables depend on the type of programme and personal factors. In addition, socioeconomic factors, living alone, taking les medication, enjoying a good health, better physical capabilities, cognitive capabilities or suffering less depression symptoms generate more adherence. Wilcox (2016) highlights the evidence that this group participates and greatly benefits from regular physical activity, however, there is a positive correlation between old age and lower levels of aerobic activity, strength training and higher levels of sedentarism. A study carried out in the USA by Joseph, Ramaswamy and Wang (2018) reports that cultural factors have a much stronger influence on behaviours and attitudes of over 65 s towards physical activity than targeted campaigns. And they include: 1. Community and cultural identity; 2. Religion; 3. Cultural attitude and gender conventions regarding physical activity; 4. Health-related cultural point of view regarding physical activity; 5 . Cultural expectations of familiarity and lack of time; 6 . Lack of role models to follow and lack of motivation; 7. Lack of exercising premises culturally adequate; 8 . Cultural expectations about body image and physical appearance.

It seems that an optimum aging based on lifestyle strategies promoting physical and mental health generates an improvement in self-efficacy beliefs and QoL among over 65s. It is suggested that, if the elderly interiorise the belief that physical activity brings about health, maybe the continuity behaviour required could be developed and adherence could be sustained in the long-term (Fernández et al., 2011; Garber et al., 2011). Based on this, questions are raised about self-efficacy being useful to predict the elderly adults' conduct towards physical activity, about how regular practice improves the belief in self-efficacy and about age and gender being determinant for the practice.

\section{METHOD}

The work presented is an empirical study with samples, based on an opinion poll administered a single time between February 2018 and May 2019. An ad hoc measuring instrument was built with a single construct predicting variable: self-efficacy and physical activity for people over 65 . A total of 712 surveys were administered, 420 of which were sent to municipal elderly people centres in the 18 city districts and nearby streets, with the collaboration of the Municipal Office for Elderly Assistance (OMAM, Spanish acronym). The remaining questionnaires were sent to some gyms, sports centres and the Turia riverbed. Participants: The analysed sample is considered representative and it was classified by gender ${ }^{1}$. It includes 682 people over 65 years of age living in the city of Valencia (276 men and 406 women).

\section{Procedure}

Based on the study and definition of self-efficacy as a variable, 10 items were created with various scales to explain such variable as a construct. Reverse items were not deemed necessary. Data were analysed using the SPS-24 software. First, a factorial analysis was conducted with a VARIMAX rotation for a single component. To verify that the data were suitable for a factorial analysis, the KMO index was obtained and the Bartlett sphericity test was applied. Both the KMO and the Bartlett sphericity test indicated that the data are suitable. The factorial analysis results indicate that all items but one saturate well (above 0.30 ) and measure the self-efficacy component (Table 1). The solution of one factor explained $48 \%$ of the total variance. The internal consistency of the 9 valid items was analysed later and offered a reliability of 0.856 . 
Table 1. Component matrix2. Extraction method principal component analysis. a. 1 components extracted (PA: Physical Activity).

\begin{tabular}{l|c}
\multicolumn{1}{|c}{ Component matrix $^{\text {a }}$} & Component \\
\hline A1. Do you practice any PA? &, 902 \\
\hline A4. How long have you been practicing PA? &, 827 \\
\hline A8. Can you easily follow PA classes? &, 787 \\
\hline A7. At what time do you practice PA? &, 752 \\
\hline A5. When do you practice PA? &, 678 \\
\hline A9. What benefits do you get from PA? &, 632 \\
\hline A3. How would you rate your mobility for PA? &, 576 \\
\hline A6. Do you practice PA alone or in company? &, 561 \\
\hline A2. How would you rate your fitness? &, 391 \\
\hline
\end{tabular}

\section{RESULTS}

The descriptive analysis of each item generated the following results (Figure 1).

Figure 1. Results of the descriptive analysis.

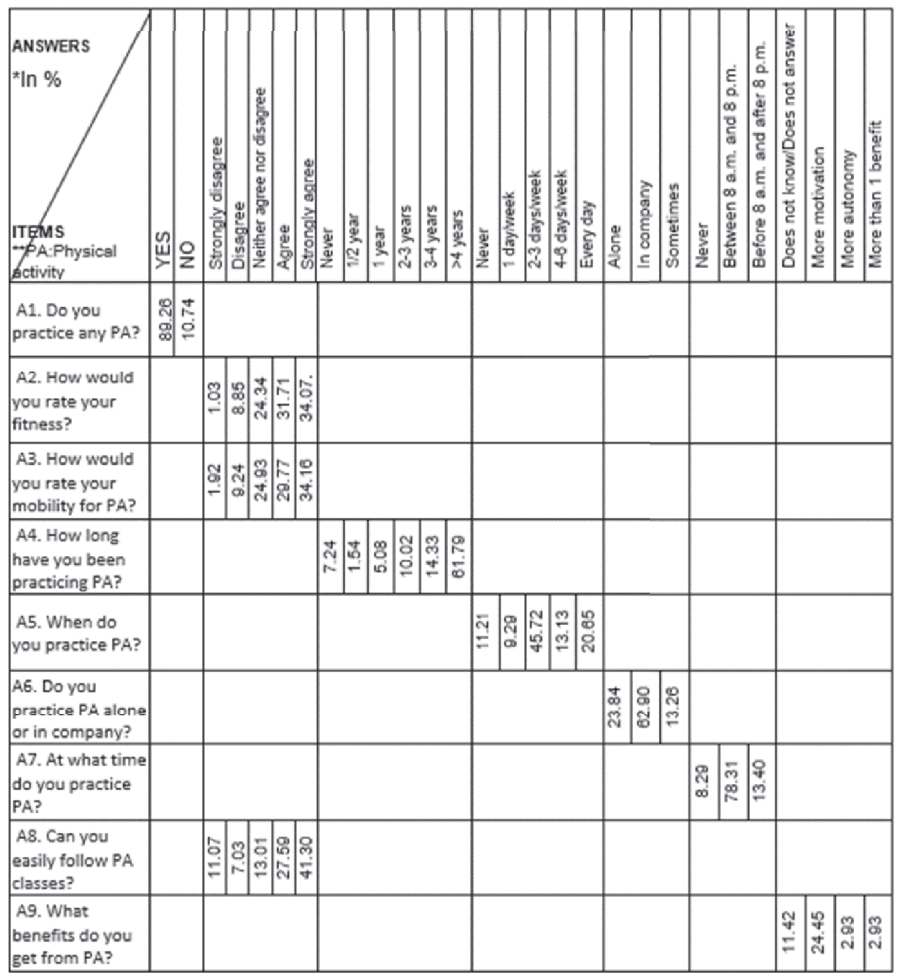




\section{SELF-EFFICACY FOR PHYSICAL ACTIVITY OF PEOPLE OVER 65}

To predict if the gender and age variables can be related to self-efficacy for physical activity, a second analysis has been carried out on Item 1. Do you practice any PA? First, considering that the age variable is of a quantitative nature, when interpreting the data, this variable was estimated to be centred around differential punctuations or some value. In this sense, a descriptive analysis of age was conducted, and the average obtained was 73.83-74 years. We obtained a new $C$ variable, which is the centred age. For males, we assigned a value of 0 and for females the value assigned was 1 . The Hosmer and Lemeshow test shows that the data observed match the theoretical model. Then, using a logistic regression analysis we checked that age and sex predict self-efficacy for physical activity. The Hosmer and Lemeschow test was also run to show that the regression model fitted the model data correctly.

In addition, the results show that 78 is the average age of people surveyed that do not practice any physical activity, compared to an average age of 73 for those who do practice. This proves that the people who do not practice are older than those who do practice. Later, we analysed the forecast probability, and the result indicated that, as age increases, the dependent variable (AGE) logi reduces the probability of physical activity. That is to say, the odds of physical activity diminish by $10 \%$ for each year increased (Figure 2).

Figure 2. A1. Forecast probability for physical activity.

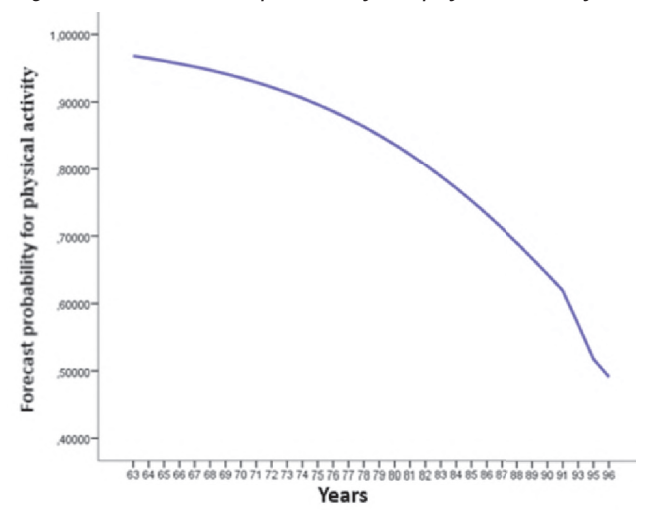

A different analysis intended to find out if gender is significant for self-efficacy, a cross table was used, and the results were as follows. In percentages, $11.96 \%$ of men and $9.92 \%$ of women do not practice any physical activity, while $88.04 \%$ of men and $90.07 \%$ of women do practice a physical activity.

For the coefficient analysis of the self-efficacy variable, a value of 1 for the gender means female and a value of 0 means male; as such, we can say from the linear regression model that women display a greater level of selfefficacy than men $\left(B_{G E N D E R}=1.081>0\right)$, while the forecast self-efficacy level for men with age around 74 is 23.211. The result indicated that, as age increases, the level of self-efficacy lowers by $10 \%$.

\section{Self-efficacy as a construct}

To design the self-efficacy construct, we used items A2. How would you rate your fitness? A3. How would you rate your mobility for PA? and A8. Can you easily follow PA classes? The main components were analysed first to check if these variables could be used to measure self-efficacy. The analysis showed significant correlations, as well as interconnections between the 3 variables. The KMO and Bartlett tests indicated that it was possible to extract the main component, self-efficacy, from the 3 variables and it would explain $74 \%$. The saturation results were high, so we can summarise variables $A 2, A 3$ and $A 8$ in one main component that we will call selfefficacy. The new variable self-efficacy can be used as an independent variable (IV) in a binary logistic regression to predict the practice of physical activity used as dependent variable (DV). The Hosmer and Lemeshow formula 
can be applied to obtain the confidence interval for the odds ratio. The logistic regression model indicated that, for each unit of increase in the self-efficacy scale (IV), the physical activity (DV) increased by $177 \%$. From here, we can understand that, as self-efficacy increases, that is, where there is a highly positive perception of fitness (A2), mobility for the physical activity (A3) and classes are followed easily (A8), the likelihood of getting involved in a physical activity increases by $177 \%$. Figure 3 shows that, as self-efficacy increases, so does the likelihood to practice physical activity.

Figure 3. Self-efficacy and physical activity.

Graph

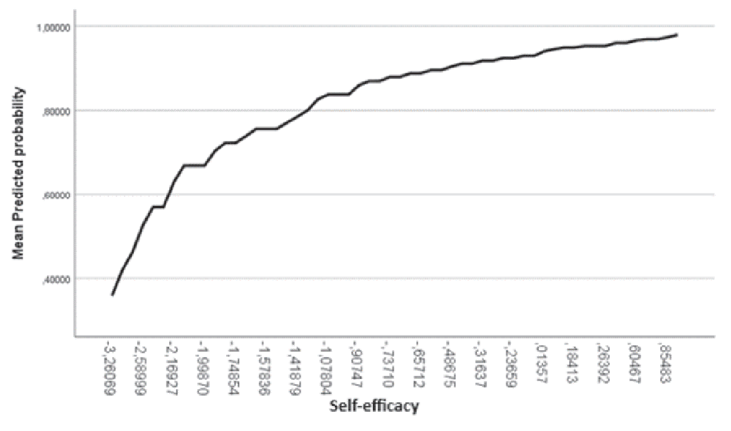

\section{DISCUSSION/CONCLUSION}

This research allows us to state that self-efficacy is not just a factor to predict the physical activity, but rather, when not present such practice would not be possible. Regular physical activity favours an improvement of the QoL and the belief on self-efficacy for the physical activity in over 65s. However, the results show the self-efficacy decreases by $10 \%$ as the elderly persons ages.

The analyses prove the validity of the scale presented to measure self-efficacy and physical activity for people over 65. They reveal that the gender is not significant when predicting self-efficacy, although, in our study, women displayed a slightly higher self-efficacy for physical activity than men. In addition, age proved to be significant to predict self-efficacy, as the analysis showed that for each year passed by, the probability to practice physical activity decreased by $10 \%$. This explains that the age of non-practising people was higher than that of practising people. This result could be justified in the following way: Given that age may reduce the physical, emotional and/or material wellbeing, it seems logical to think that it leads to depression and/or dementia conditions, as described by the literature, and, considering that self-efficacy is directly related to the fitness, getting older negatively affects the health conduct of elderly people. This results in lower levels of self-efficacy. In this regard, it is suggested that habits leading to healthy behaviours should be generated from childhood (family and school). These habits would be conducive to promote a better physical condition throughout the entire lifecycle, including any stage of old age. Thus, for future assessments, it should be considered that over 65 s that went to school with physical activity as a subject will have a greater self-efficacy for healthy behaviours and physical activity than those who did not attend school or, if they did, such subject was not in their programme.

The field notes from some study participants reveal that activity programmes for people over 65 including dancing are the most sought after and the most prevalent. Currently, due to the problems in finding a dancing partner, line dancing is in fashion and enjoys a significant participation, both from men and women. Taking all this into consideration, it is suggested that, to promote self-efficacy in elderly people for physical activity, the programmes should include line dancing in the last 10 minutes of each session. 
Finally, given that social persuasion also increases self-efficacy, it is suggested that those in charge of physical activity programmes for the elderly should verbally encourage and recognise their efforts and achievements, no matter how small, considering that for these people, leaving their home and spending time with their peers is as beneficial for their health as regular physical activity.

\section{BIBLIOGRAPHIC REFERENCES}

AYTO. VCIA. Estadístico. (2017). In Ayuntamiento de Valencia (Ed.), Recull estadístic de la Ciutat de València [Informe estadístico de la ciudad de Valencia]. Valencia: Retrieved from http://www.valencia.es/ayuntamiento/webs/estadistica/Recull/Recull_Castellano.pdf

Bandura, A. (1983). Principios de modificación de conducta [Principles of behavior modification]. Salamanca: SÍGUEME.

Bandura, A. (1987). Pensamiento y acción [Social Foundations of Thought and Action]. Barcelona: Martinez Roca.

Bandura, A. (2004). In Albert Bandura (Ed.), Auto-eficacia: Cómo afrontamos los cambios de la sociedad actual [Sefl-Efficacy in Changing Society] (Jasone Aldekoa Trans.). Sevilla: Desclée de Brouwer.

Blazer, D. G. (2009). The myth, history, and science of aging. In David C. Steffens, Dan G. Blazer \& Mugdha E. Thakur (Ed.), The american psychiatric publishing textbook of geriatric psychiatry (4th ed., pp. 3-19). USA: American Psychiatric Publishing.

Brown, E., Kaiser, R.M., \& Gellis, D. (2007). Screening and assessment of late-life depression in home healthcare: Issues and challenges. Annals of Long-Term Care, 15(10)

Capalb, D.J., O'Halloran,P. \& Liamputtong, P. (2014). Why older people engage in physical activity: An exploratory study of participants in a community-based walking program. Australian Journal of Primary Health, 20(1), 74-78. doi:10.1071/PY12090

Cerin, E., Conway, T. L., Adams, M. A., Barnett, A., Cain, K. L., Owen, N., (. . .) Sallis, J. F. (2018). Objectivelyassessed neighbourhood destination accessibility and physical activity in adults from 10 countries: An analysis of moderators and perceptions as mediators. Social Science \& Medicine (1982), 211, 282-293. doi:S0277-9536(18)30342-3 [pii]

Chaudhury, H., Campo, M., Michael, Y., \& Mahmood, A. (2016). Neighbourhood environment and physical activity in older adults. Social Science \& Medicine, 149, 104-113. doi:10.1016/j.socscimed.2015.12.011

Cohen, G. D. (1979). Research on aging: A piece of the puzzle. Gerontologist, 19(5), 503-508. doi:doi:10.1093/geront/19.5_Part_1.503

Emile, M., Chalabaev, A., Stephan, Y., Corrion, K., \& d'Arripe-Longueville, F. (2014). Aging stereotypes and active lifestyle: Personal correlates of stereotype internalization and relationships with level of physical activity among older adults. Psychology of Sport and Exercise, 15(2), 198-204. doi:10.1016/j.psychsport.2013.11.002

Engel, G. L. (2012). The need for a new medical model: A challenge for biomedicine. Psychodynamic Psychiatry, 40(3), 377-396. doi:10.1521/pdps.2012.40.3.377

Faienza, M. F., Lassandro, G., Chiarito, M., Valente, F., Ciaccia, L., \& Giordano, P. (2020). How physical activity across the lifespan can reduce the impact of bone ageing: A literature review. International Journal of Environmental Research and Public Health, 17(6), 1862. doi:10.3390/ijerph17061862

Fernández, T., Medina, S., Herrera, I. M., Rueda, S., \& Fernández, A. (2011). Construcción y validación de una escala de autoeficacia para la actividad física. Revista Española de Salud Pública, 85(4), 405-417. Retrieved from http://scielo.isciii.es/scielo.php?script=sci_arttext\&pid=\$1135-57272011000400009

Franco, M. R., Howard, K., Sherrington, C., Ferreira, P. H., Rose, J., (...) Ferreira, M. L. (2015). Eliciting older people's preferences for exercise programs: A best-worst scaling choice experiment. Journal of Physiotherapy, 61(1), 34-41. doi:http://dx.doi.org/10.1016/j.jphys.2014.11.001 
Garber, C. E., Blissmer, B., Deschenes, M. R., Franklin, B. A., Lamonte, M. J., Lee, I. M., Nieman, D. C., Swain, D. P., \& ACSM. American College of Sports Medicine. (2011). Quantity and quality of exercise for developing and maintaining cardiorespiratory, musculoskeletal, and neuromotor fitness in apparently healthy adults: guidance for prescribing exercise. Medicine \& Science in Sports \& Exercise, 43(7), 1334-1359. doi:10.1249/MSS.0b013e318213fefb

Garcia, F., Martinez, I., Balluerka, N., Cruise, E., Garcia, 0. F., \& Serra, E. (2018). Validation of the five-factor selfconcept questionnaire AF5 in brazil: Testing factor structure and measurement invariance across language (Brazilian and Spanish), gender, and age. Frontiers in Psychology, 9, 2250. doi:10.3389/fpsyg.2018.02250

Hawkesworth, S., Silverwood, R. J., Armstrong, B., Pliakas, T., Nanchalal, K., Jefferis, B. J., (. . .) Lock, K. (2018). Investigating associations between the built environment and physical activity among older people in $20 \mathrm{UK}$ towns. Journal of Epidemiology and Community Health, 72(2), 121-131. doi:10.1136/jech-2017-209440

IMSERSO. (2010). In IMSERSO (Ed.), Libro blanco del envejecimiento activo. Temas. Retrieved from https://www.aepumayores.org/sites/default/files/EXTRACTO_LIBRO_BLANC0_12-10-10_def.pdf

Jones, R. L. (2006). 'Older people' talking as if they are not older people: Positioning theory as an explanation. Journal of Aging Studies, 20(1), 79-91. doi:http://dx.doi.org/10.1016/j.jaging.2004.12.003

Joseph, N. M., Ramaswamy, P., \& Wang, J. (2018). Cultural factors associated with physical activity among U.S. adults: An integrative revie. Applied Nursing Research: ANR, 42, 98-110. doi:10.1016/j.apnr.2018.06.006

Kaiser, R. M. (2015). Psysiologycal and clinical considerations of a geriatric patient care. In David C. Steffens, Dan G. Blazer \& Mugdha E. Thakur (Ed.), The American psychiatric publishing. textbook of geriatric psychiatry (5th ed., pp. 33-61). Arlington, VA. USA: The American Psychiatric Publishing. Retrieved from https://books.google.es/books?hl=es\&id=hakvCgAAQBAJ\&q=The +longanticipated+retirement\#v=0nepage\&q\&f=false

Kaiser, R. M. (2017). Should home visits be mandatory for medical students?. VA Perspectives. Frontiers. American Academy of Home Care Medicine (AAHCM), 31(1), 3.

Kang, H. W., Park, M., \& Wallace Hernandez, J. P. (2018). The impact of perceived social support, loneliness, and physical activity on quality of life in south Korean older adults. Journal of Sport and Health Science, 7(2), 237-244. doi:10.1016/j.jshs.2016.05.003

Kingston, A., Wohland, P., Wittenberg, R., Robinson, L., Brayne, C., \& Jagger, C. (2017). Is late-life dependency increasing or not? A comparison of the cognitive function and ageing sudies. Lancet, 390, 1676-84. doi:10.1016/S0140-6736(17)31575-1

Lázaro, Y., Doistua, J., y Lazcano, I. (2019). La práctica deportiva en la educación del ocio como herramienta para el envejecimiento activo. Revista Española de Educación Física y Deportes (REEFD), 426, 370-376. Retrieved from https://www.reefd.es/index.php/reefd/article/view/802/680

Li-Tang, T., Rantakokko, M., Viljanen, A., Rantajanaho, M., Eronen, J., (...) Portegijs, E. (2016). Associations between reasons to go outdoors and objectively-measured walking activity in various life-space areas among older people. Journal of Aging \& Physical Activity, 24(1), 85-91. doi:10.1123/japa.2014-0292

Meléndez, J. C., Navarro, E., Oliver, A., \& Tomás, J. M. (2009). La satisfacción vital en los mayores. factores sociodemográficos. Boletín De Psicología, 95, 29-42.

Meléndez, J. C., Satorres, E., \& Delhom, I. (2020). Personality and coping. what traits predict adaptive strategies?. Anales De Psicologia, 36(1), 39-45. doi:10.6018/analesps.349591

Meléndez, J. C., Tomás, J. M., \& Navarro, E. (2011). Everyday life activities and well-being: Their relationships with age and gender in the elderly. [Actividades de la vida diaria y bienestar y su relación con la edad y el género en la vejez] Anales De Psicologia, 27(1), 164-169.

Myers, J., Prakash, M., Froelicher, V., Do, D., Partington, S., \& Atwood, J. E. (2002). Exercise capacity and mortality among men referred for exercise testing. N Engl J Med, 346(11), 793-801. doi:10.1056/NEJMoa011858 
Ortiz-Alonso, J., Bustamante-Ara, N., Valenzuela, P. L., Vidán-Astiz, M., Rodríguez-Romo, G., Mayordomo-Cava, J., Javier-González, M., Hidalgo-Gamarra, M., Lopéz-Tatis, M., Valades-Malagón, M. I., Santos-Lozano, A., Lucia, A., \& Serra-Rexach, J. A. (2020). Effect of a simple exercise program on hospitalization-associated disability in older patients: A randomized controlled trial. Journal of the American Medical Directors Association, 21(4), 531-537.e1. doi:org/10.1016/j.jamda.2019.11.027

Picorelli, A. M. A., \& Máximo, L. S., Sirineu, D., Felício, D. \& Sherrington, C. (2014). Adherence to exercise programs for older people is influenced by program characteristics and personal factors. Journal of Physiotherapy, 60(3), 151-156. doi:10.1016/j.jphys.2014.06.012

Pinazo, S. (2018). In Fundación Pilares. Universidad de Valencia (Ed.), Personas mayores centenarias, ejemplo de resiliencia y buen envejecer. Valencia, España: Retrieved from http://www.fundacionpilares.org/modeloyambiente/docs/buenas-practicas/ficha-tecnica/2018-BP36-U.VALENCIA-Centenarias.pdf

Ruiz-Montero, P. J., Ramiro, M. T., Sánchez, T. R., \& Marmol, E. G. (2020). Efectos de un programa de ejercicio físico pilates-aerobic sobre el nivel de capacidad funcional y la calidad de vida relacionada con la salud física y mental en mujeres mayores. Psychology, Society, \& Education, 12(2), 91-105.

Serra-Rexach, J., Bustamante-Ara, N., Hierro Villarán, M., González Gil, P., Sanz Ibáñez, M. J., Blanco Sanz, N., (. . .) Lucia, A. (2011). Short-term, light- to moderate-intensity exercise training improves leg muscle strength in the oldest old: A randomized controlled trial. Journal of the American Geriatrics Society, 59(4), 594-602. doi:10.1111/j.1532-5415.2011.03356.x

Verdejo, I. C., \& Calvo, C. B. (2017). Memoria cotidiana: Dimensiones y pautas de declive en adultos sanos./everyday memory: Dimensions and patterns of decline in healthy adults. Psychology, Society, \& Education, 9(3), 405-418.

Wen, M., Li, L., \& Su, D. (2014). Physical activity and mortality among middle-aged and older adults in the united states. Journal of Physical Activity \& Health, 11(2), 303-312.

WHO. World Health Organization. (2010). Global recommendations on physical activity for health. Switzerland: Retrieved from https://www.who.int/dietphysicalactivity/publications/9789241599979/en/

Wilcox, S. (2016). Behavioral interventions and physical activity in older adults: Gains and gaps. Kinesiology Review, 5(1), 57-64. doi:10.1123/kr.2015-0053

\section{NOTAS}

${ }^{1}$ This number was obtained using the proportional affixation procedure, whose result (error margin $=1.05$ ) shows that for a total population of 161,659 people over 65, including 65,158 men and 96,501 women (AYT0. VCIA. Estadístico, 2017, p. 4), the sample must contain a total of 682 people (276 men and 406 women). 